Rabaska

Revue d'ethnologie de l'Amérique française

\title{
Le Diable à la danse
}

Volume 5, 2007

URI : https://id.erudit.org/iderudit/019030ar

DOI : https://doi.org/10.7202/019030ar

Aller au sommaire du numéro

\section{Éditeur(s)}

Société québécoise d'ethnologie

ISSN

1703-7433 (imprimé)

1916-7350 (numérique)

Découvrir la revue

Citer ce document

(2007). Le Diable à la danse. Rabaska, 5, 103-103.

https://doi.org/10.7202/019030ar

Ce document est protégé par la loi sur le droit d'auteur. L'utilisation des services d'Érudit (y compris la reproduction) est assujettie à sa politique d'utilisation que vous pouvez consulter en ligne.

https://apropos.erudit.org/fr/usagers/politique-dutilisation/
Cet article est diffusé et préservé par Érudit.

Érudit est un consortium interuniversitaire sans but lucratif composé de l'Université de Montréal, l'Université Laval et l'Université du Québec à Montréal. Il a pour mission la promotion et la valorisation de la recherche. https://www.erudit.org/fr/ 


\title{
Place publique
}

\author{
Points de vue / livre
}

\section{Le Diable à la danse}

Publication attendue depuis longtemps que cette thèse de Jean Du Berger soutenue en décembre 1980 à l'Université Laval. Dirigée par Luc Lacourcière, elle semblait ne devoir jamais voir le jour, victime peut-être d'un maléfice diabolique. Mais voilà que l'auteur, ayant domestiqué le « goût amer » de la soutenance et vaincu le découragement qui paralysait le travail de mise à jour nécessité par un délai d'un quart de siècle, exhume enfin du « cimetière », où sont alignés les chefs-d'œuvre des anciens apprentis, ce « classique » dont on se prenait à croire que la tradition orale ferait seule son profit. Pour marquer cet événement, épiphanie ou apothéose selon l'appréciation de l'un ou de l'autre, deux spécialistes de l'oralité livrent ici leur point de vue : l'ethnologue Bertrand Bergeron, lecteur attentif du texte fondateur de son maître, et Lise Gauvin, spécialiste de la littérature québécoise des $\mathrm{XIX}^{\mathrm{e}}$ et $\mathrm{XX}^{\mathrm{e}}$ siècles.

Jean Du Berger, Le Diable à la danse, Québec, CÉLAT et Les Presses de l'Université Laval, « Ethnologie de l'Amérique française », 2006, 246 p. ISBN 2-7637-8377-5.

\section{Un classique de la recherche en tradition orale}

Bertrand Bergeron

Collège d'Alma

Dès la première note de son «Avant-propos », Jean Du Berger y va d'une remarque désenchantée. Parlant de toutes ces thèses de doctorat déposées à l'Université Laval, il avoue : "J'ai toujours eu l'impression de visiter un cimetière. "Untel mort à la recherche en telle année " " (p. 11). Loin de moi de vouloir minimiser, voire dissiper, ce sentiment, mais il arrive aux cimetières de rendre leurs morts et cela nous vaut parfois des résurrections espérées et pleines de surprises comme Le Diable à la danse. 